\title{
KETERKAITAN ANTARA PERSEPSI PENTINGNYA AKREDITASI RUMAH SAKIT DENGAN PARTISIPASI, KOMITMEN, KEPUASAN KERJA, DAN KINERJA KARYAWAN
}

\author{
Safil Rudiarto Hendroyogi, Mugi Harsono \\ Magister Manajemen FEB UNS. \\ Jl. Ir. Sutami 36 A Surakarta \\ Email: safilrso.@gmail.com
}

\begin{abstract}
Accreditation of hospitals is very important to do as an effort to improve quality and patient safety. Many of the standards that must be implemented in hospitals, requiring an optimal role for all stakeholders (stakeholders), especially the participation of employees. This condition greatly be affected by employees' perception of the benefits of hospital accreditation. The purpose of the study is to examine employee perceptions about the benefits of accreditation associated with participation, satisfaction, commitment and employee performance. The benefits of this research are expected to be input for the hospital management, to encourage all employees to learn about the hospital accreditation standards. Data from the study was obtained by means of a survey of hospital employees, using a Likert scale. Furthermore, the data do tests of validity and reliability and path analysis (path analysis), to see the correlation between variables. Research conducted on 259 randomly selected respondents, composed of physicians, nurses, medical support, as well as administrative personnel. The results of this study indicate that there is significant influence between the perception of the benefits of accreditation to the participation of accreditation with a significance level of 0.000, the perception of the benefits of accreditation with the organizational commitment amounting to 0,016, the perception of the benefits of accreditation and job satisfaction amounting to 0,000 , participation accreditation with organizational commitment amounting to 0,039, accreditation participation with satisfaction employment amounting to 0,000, accreditation participation with performance amounting to 0,000, job satisfaction with organizational commitment amounting to 0,039, organizational commitment with performance amounting to 0,018 , job satisfaction with performance amounting to 0.000 .
\end{abstract}

Keywords: Accreditation of hospitals, participation, satisfaction, commitment and performance.

\section{Pendahuluan}

Sebagai institusi yang bergerak di bidang pelayanan kesehatan, rumah sakit mempunyai peran penting dalam upaya peningkatan kualitas kehidupan masyarakat. Pertambahan jumlah rumah sakit terlihat begitu pesat. Berdasarkan data dari kementerian kesehatan disebutkan bahwa pada tahun 2012 jumlah rumah sakit di Indonesia sebanyak 2.083 unit, sedangkan pada tahun 2014 jumlah rumah sakit teregistrasi 2.520 unit, yang berarti dalam waktu 2 tahun bertambah sekitar 21\% (Kemenkes RI, 2016). Kondisi tersebut menyebabkan akan terjadi persaingan di antara rumah sakit untuk selalu berupaya memperbaiki pelayanan agar diminati 
masyarakat. Seperti yang disampaikan oleh Griffin (2007) bahwa produktivitas dan kualitas adalah alat bersaing dari suatu perusahaan. Hal ini memerlukan partisipasi semua pihak dalam perusahaan, terutama oleh karyawan. Perusahaan harus berusaha melakukan pemberdayaan karyawannya.

Keberadaan rumah sakit saat ini dalam menyikapi persaingan, juga perlu berusaha meningkatkan produktivitas dengan standar yang ditetapkan. Momentum akreditasi rumah sakit versi 2012 perlu dimanfaatkan secara baik bagi para pimpinan. Menurut Sutoto et al. (2013) sejak pengggunaan instrumen standar akreditasi rumah sakit versi 2012, terdapat perubahan yang cukup bermakna yaitu perubahan standar yang semula berfokus kepada pemberi pelayanan, diarahkan menjadi berfokus kepada pasien. Implementasi standar tersebut harus melibatkan seluruh petugas dalam proses akreditasi.

Ketentuan akreditasi sebagai salah satu kewajiban rumah sakit harus dilakukan setiap minimal 1 kali dalam tiga tahun seperti yang tercantum dalam undang-undang no. 44 Tahun 2009 tentang rumah sakit pasal 40 ayat 1. Kegiatan tersebut dilakukan sebagai upaya peningkatan mutu dan keselamatan pasien. Hampir setiap tindakan medis di rumah sakit memliki risiko yang perlu antisipasi seawal mungkin. Begitu banyak orang dan profesi terlibat dalam penanganan pasien. Kegagalan dalam pengelolaan terhadap kondisi tersebut, dapat meningkatkan risiko kejadian tidak diharapkan di rumah sakit.

Seperti yang disebutkan dalam buku Panduan Nasional Keselamatan Pasien di Rumah Sakit (2006), bahwa berdasarkan laporan Institute of Medicine (IOM), Amerika Serikat tahun 2000 dari berbagai negara terdapat sekitar 3 s/d 16\% kejadian tidak diharapkan terjadi dalam pelayanan pasien rawat inap di rumah sakit. Angka kematian akibat kejadian tidak diharapkan pada pasien rawat inap di seluruh Amerika berkisar 44.000-98.000 per tahun.

Beberapa berita di surat kabar dapat terbaca tentang kejadian yang tidak diharapkan terjadi di rumah sakit, misalnya kematian yang terjadi pada pasien tidak berkaitan dengan penyakitnya atau cacat. Kejadian tersebut akhirnya dapat menjadi kasus hukum. Peristiwa lainnya misalnya pasien jatuh, nyaris salah pasien, dan lain-lain dapat terjadi. Dalam buku panduan keselamatan pasien dari Departemen Kesehatan RI (2006) disebutkan bahwa peristiwa yang tidak diinginkan di rumah sakit merupakan kesalahan dalam proses pelayanan yang sebetulnya dapat dicegah melalui rencana pelayanan yang komprehensif dengan melibatkan pasien berdasarkan haknya. Oleh karena itu program keselamatan pasien (patient safety), harus dibudayakan yang tentunya akan mendorong karyawan bekerja lebih berkualitas.

Akreditasi rumah sakit mempunyai dampak positif terhadap kualitas perawatan yang diberikan kepada pasien dan kepuasan pasien (Yildiz, 2014). Penerapan standar akreditasi mendorong perubahan pelayanan rumah sakit yang lebih berkualitas dan peningkatan kerja sama antara displin profesi dalam perawatan pasien (Manzo, 2012). Implementasi standar akreditasi rumah sakit versi 2012 mempunyai manfaat yang antara lain, rumah sakit lebih mendengarkan keluhan/ kritik dan saran dari pasien dan keluarganya. Di samping itu rumah sakit juga akan berusaha menghormati hak-hak pasien dan melibatkan pasien dalam proses perawatan sebagai mitra. Pasien dan keluarganya diajak berdialog dalam menentukan perawatan yang terbaik. Dampak yang diharapkan bahwa rumah sakit yang melakukan upaya peningkatan mutu pelayanan dan keselamatan pasien, dapat meningkatkan kepercayaan masyarakat (Rahma, 2012).

Rumah sakit Ortopedi telah dilakukan beberapa kali survei oleh Komisi Akreditasi Rumah Sakit (KARS) yaitu tahun 2007, 2010, dan 2014 yang semuanya dinyatakan lulus. Sistem akreditasi rumah sakit pada tahun 2007 dan 2010 yang paling berperan dalam mempersiapkan pelaksanaan survei adalah tim akreditasi yang dibentuk oleh direktur. Persiapan yang dilakukan lebih berupa 
dokumen yang diperlukan untuk pemenuhan standar. Keterlibatan karyawan lebih banyak pada tim akreditasi, tidak melibatkan seluruh karyawan.

Sejak survei yang dilakukan KARS pada bulan Oktober tahun 2014, terdapat banyak sekali perubahan standar yang harus diterapkan oleh rumah sakit. Proses persiapan yang dilakukan mulai melibatkan seluruh karyawan rumah sakit dan komponen pendukungnya. Berbagai kendala terjadi terutama kebutuhan sarana parasarana yang belum sesuai standar, termasuk upaya peningkatan partisipasi dan komitmen karyawan.

Begitu banyak profesi yang bekerja di Rumah Sakit Ortopedi Prof. Dr. R. Soeharso Surakarta, misalnya dokter, perawat, penunjang medik (radiografer, fisioterapi, nutrisionist, dan lain-lain). Di samping itu ada karyawan yang bertindak sebagai administrasi yang meliputi bidang akuntansi, hukum, komunikasi, komputer, dan lain-lain yang harus mendukung proses pelayanan pasien. Masing-masing dari mereka dapat mempunyai persepsi yang berbeda terhadap penerapan standar akreditasi.

Jenis kegiatan atau pelayanan rumah sakit bukan semata-mata satu jenis pelayanan kesehatan, tetapi juga pelayanan lain yang bersifat pendukung (laundry, kemudahan pendaftaran, kemudahan pembayaran, dan lain-lain) yang harus juga dilakukan sesuai standar yang ditetapkan. Begitu juga jenis dan tingkat pendidikan, jenis pekerjaannya, serta jenis tanggung jawab yang tentunya dapat berpotensi mempengaruhi persepsi dan partisipasi terhadap akreditasi rumah sakit.

Menurut Kaswan (2015) salah satu bentuk partisipasi aktif untuk mencapai tujuan organisasi adalah pemberian peran oleh pimpinan/manajemen kepada karyawan untuk mengambil keputusan yang sesuai dengan bidang pekerjaannya. Partisipasi secara sederhana berarti pengambilan keputusan atau pemecahan permasalahan bersama di antara karyawan dengan manajemen. Banyak sekali keputusan yang harus dilakukan karyawan ketika melakukan pelayanan kepada pasien.
Persepsi yang sama mengenai manfaat dilaksanakannya akreditasi rumah sakit akan membuat standar akreditasi menjadi pedoman bagi seluruh karyawan terhadap pekerjaan rutinnya. Pandangan negatif yang menganggap bahwa akreditasi ini akan menjadi beban yang menambah-nambah pekerjaan karyawan harus diminimalkan. Kerjasama dan semangat yang sama tinggi dari semua karyawan perlu didorong sebagai upaya pelayanan kesehatan berkualitas tinggi bagi masyarakat di rumah sakit (Rahma, 2012).

Yang menjadi perhatian terutama dalam memelihara penerapan standar akreditasi tidak mudah. Perlu ada kesamaan persepsi tentang manfaat akreditasi rumah sakit, agar semua karyawan berperan aktif, dengan dorongan dan monitoring para pimpinan. Menurut Robbins \& Judge (2013) menyatakan bahwa persepsi dapat berpengaruh langsung terhadap partisipasi. Partisipasi dapat meningkatkan komitmen terhadap keputusan. Persepsi mempunyai peran positif terhadap kinerja karyawan atau produktivitas kerja.

Partisipasi karyawan mempunyai pengaruh positif terhadap kepuasan kerja, produktivitas kerja dan komitmen karyawan (Bhatti \& Qureshi, 2007). Keterlibatan mempunyai pengaruh signifikan terhadap kepuasan kerja pada dokter (Khan et al., 2011). Bentuk partisipasi karyawan yang dilakukan adalah kepeduliannya untuk selalu berusaha melakukan kegiatan dengan penerapan standar akreditasi sesuai dengan bidang dan tanggung jawabnya. Penerapan standar akreditasi di rumah sakit perlu dimonitor terus menerus, disebabkan setiap tiga tahun sekali akan dilakukan reakreditasi dan setiap tahun dilakukan verifikasi oleh KARS.

Setiap tiga tahun akan disurvei ulang dengan melihat penerapan seluruh standar, sedangkanpadaverifikasitahunantidakmelihat seluruhstandar, tetapiberdasarkan padaelemen standar tertentu yang belum dilaksanakan secara baik (berdasarkan survei). Kondisi ini memerlukan komitmen dan partisipasi seluruh karyawan terhadap pelaksanaan akreditasi secara berkesinambungan. Standar- 
standar yang dijadikan komponen penilaian dalam survei akreditasi harus dipenuhi dan diimplementasikan dalam jangka panjang atau terus menerus bukan hanya pada saat survei akreditasi.

Penelitian yang berkaitan dengan persepsi karyawan tentang manfaat penerapan standar akreditasi ini menarik untuk dikaji lebih dalam. Persepsi yang ada dapat sangat heterogen, yang tentunya juga dapat bekaitan dengan partisipasi, komitmen dan kepuasan kerja. Dengan ini tujuan penelitian ini adalah menganalisis keterkaitan antara persepsi pentingnya akreditasi rumah sakit dengan partisipasi, komitmen, kepuasan kerja, dan kinerja karyawan.

\section{Tinjauan Pustaka}

\section{Persepsi}

Kotler (2012) menjelaskan persepsi sebagai suatu proses seseorang menyeleksi, mengatur, dan menginterpretasikan terhadap informasi yang diterimanya, yang selanjutnya tercipta gambaran yang mempunyai makna. Sebutan persepsi dalam Kamus Besar Bahasa Indonesia(KBBI), diartikan sebagai tanggapan (penerimaan) langsung dari sesuatu atau suatu proses seseorang mengetahui beberapa hal melalui panca inderanya.

Proses yang dialami setiap individu terjadi secara berbeda. Setiap manusia sejak kecil, telah mengalami proses interaksi dengan lingkungannya banyak hal terjadi pada setiap orang,. Banyak kejadian yang dialami oleh manusia akan membentuk persepsi, sebagai upaya untuk beradaptasi dengan lingkungannya. Proses pembentukan persepsi pada individu dipengaruhi oleh berbagai faktor. Kotler (2012) mengatakan bahwa faktor-faktor yang mempengaruhi persepsi seseorang adalah adanya katakteristik orang yang dipersepsikan dan faktor situasional yang tentunya dapat berbeda.

Robbins (2013) mengatakan seseorang dapat berperilaku sesuai dengan persepsi yang dimiliki. Masing-masing individu bila memandang pada satu benda yang sama, dapat mempunyai persepsi berbeda-beda.
Ada beberapa faktor yang berperan dalam membentuk persepsi seseorang. Persepsi dalam beberapa hal dapat dipengaruhi dari pihak pelaku persepsi (perceiver), sementara pada lainnya dapat berada pada obyeknya atau target yang dipersepsikan, di samping itu dapat terjadi dalam konteks situasi dimana persepsi itu dilakukan.

Kondisi manusia yang beragam terutama yang berkaitan dengan faktor-faktor yang mempengaruhinya akan membuat persepsinya menjadi berbeda-beda. Organisasi yang dibentuk terdiri lebih dari dua orang tentu juga dapat mempunyai beragam persepsi. Menurut Sutradhar (2014) dinyatakan bahwa di antara yang paling dominan dalam mempengaruhi perilaku organisasi adalah adanya persepsi yang dimiliki setiap anggota organisasi.

\section{Partisipasi}

Gibson (2012) mengatakan bahwa partisipasi telah menjadi bagian yang tidak terpisahkan dalam kehidupan bekerja. Ada sejumlah manfaat untuk organisasi dan pribadi karyawan yang diperoleh dari partisipasi. Bila partisipasi dikelola secara baik, maka akan dapat meningkatkan efektivitas, meningkatkan prestasi, produktivitas dan kepuasan kerja. Menurut Dewi (2006), partisipasi dapat menjadi salah satu cara untuk memotivasi orang, disebabkan partisipasi lebih menekankan pada segi psikologis dalam arti dengan melibatkan seseorang akan membuatnya ikut bertanggung jawab.

Menurut Robbins \& Coulter (2012) partisipasi karyawan akan timbul dengan melibatkan orang dalam proses pengambilan keputusan. Partisipasi memungkinkan secara individu untuk mengungkapkan perasaannya, meningkatkan kualitas proses, dan meningkatkan komitmen karyawan hingga keputusan akhir. Karyawan yang mempunyai tingkat partisipasi kerja yang tinggi akan berusaha mengenali dan memperhatikan jenis pekerjaan yang dilakukannya. Tingkat partisipasi yang tinggi terkait dengan tingkat absensi yang lebih sedikit dan tingkat pengunduran diri karyawan yang lebih rendah. 
Menurut Kaswan (2015) partisipasi merupakan keterlibatan mental dan emosional yang berarti keterlibatan bersifat menyeluruh pada diri seseorang. Keterlibatan ini lebih bersifat psikologis dari pada fisik. Pada prinsipnya orang lebih termotivasi, ketika dilibatkan untuk menetapkan tujuan bersama dalam organisasi. Hal ini akan membuat orang tersebut mempunyai minat lebih besar dalam ikut mengambil keputusan dan pemecahan masalah.

\section{Komitmen}

Komitmen organisasional didefinisikan sebagai suatu keadaan di mana seorang karyawan memihak organisasi tertentu serta tujuan-tujuan dan keinginannya untuk mempertahankan keanggotaan dalam organisasi tersebut (Robbins \& Judge, 2013). Menurut Mowday et al., (1979), komitmen organisasi didefinisikan sebagai berikut:

a. Keinginan kuat untuk tetap sebagai anggota organisasi tertentu;

b. Keinginan untuk berusaha keras sesuai keinginan organisasi;

c. Keyakinan tertentu, dan penerimaan nilai dan tujuan organisasi.

Menurut Allen \& Meyer (1990) terdapat tiga dimensi tentang komitmen organisasional, yaitu antara lain :

a. Komponen afektif berkaitan dengan emosional, identifikasi, dan keterlibatan karyawan di dalam suatu organisasi. Keterkaitan emosional ini terbentuk karena karyawan setuju dengan tujuan dasar dan nilai-nilai organisasi, serta mengerti untuk apa organisasi tersebut berdiri. Karyawan dengan tingkat komitmen afektif yang tinggi akan memilih untuk tetap tinggal dalam organisasi untuk menyokong organisasi dalam mencapai misinya.

b. Komponen normatif merupakan perasaan karyawan tentang kewajiban yang harus ia berikan kepada organisasi. Kewajiban untuk tetap tinggal dalam organisasi disebabkan karena tekanan dari pihak lain. Karyawan dengan tingkat komitmen normatif yang tinggi sangat peduli terhadap apa yang akan dipikirkan orang lain bila ia keluar dari organisasi tempatnya bekerja. Karyawan seperti ini akan merasa enggan untuk mengecewakan atasannya dan khawatir akan dicap buruk oleh rekan kerjanya bila ia keluar dari pekerjaan tersebut.

c. Komponen continuance (kelanjutan) komponen berdasarkan persepsi karyawan tentang kerugian yang akan dihadapinya jika ia meninggalkan organisasi. Semakin lama seseorang tinggal dalam sebuah organisasi, ia akan semakin tidak rela kehilangan apa yang telah mereka investasikan di organisasi tersebut, misalnya senioritas, kesempatan promosi, perencanaan pensiun, hubungan dengan rekan kerja. Karyawan dengan tingkat komitmen kelanjutan yang tinggi akan memilih untuk tetap tinggal dalm organisasinya dikarenakan tidak ingin mengambil risiko kehilangan hal-hal tersebut.

Setiap komponen memiliki dasar yang berbeda. Karyawan dengan komponen afektif tinggi masih bergabung dengan organisasi karena keinginan tetap menjadi anggota organisasi. Sementara itu karyawan dengan tingkat continuance tinggi, tetap bergabung dengan organisasi tersebut karena mereka membutuhkan organisasi. Pegawai yang memiliki komponen normatif yang tinggi, tetap menjadi anggota organisasi karena mereka merasa harus melakukannya.

\section{Kepuasan Kerja}

Menurut Robbins \& Judge (2013) menyatakan bahwa kepuasan kerja merupakan sikap umum seorang individu terhadap pekerjaannya. Seorang dengan sikap kepuasan tinggi menunjukkan sikap yang positif terhadap kerja, seseorang yang tidak puas terhadap pekerjaannya menunjukkan sikap yang negatif terhadap pekerjaan tersebut. Menurut Gibson (2012) menyatakan kepuasan kerja sebagai sikap 
yang dimiliki para pekerja tentang pekerjaan mereka. Hal itu merupakan hasil dari persepsi mereka tentang pekerjaan. Kepuasan kerja merupakan respons afektif atau emosional terhadap berbagai segi atau aspek pekerjaan seseorang sehingga kepuasan kerja bukan merupakan konsep tunggal. Seseorang dapat relatif puas dengan salah satu aspek pekerjaan dan tidak puas dengan satu atau lebih aspek lainnya.

Menurut Kaswan (2015) terdapat tiga dimensi tentang kepuasan kerja yang dapat diterima, yaitu: kepuasan kerja merupakan respons emosional terhadap situasi kerja, sering ditentukan menurut seberapa baik hasil yang dicapai memenuhi kebutuhan dan harapan, juga merepresentasikan beberapa sikap terkait dengan pekerjaan. Di samping itu ada sejumlah faktor yang mempengaruhi tingkat kepuasan kerja, antara lain tingkat gaji dan tunjangan, persepsi rasa adil terhadap sistem promosi di dalam organisasi, kualitas kondisi kerja, kepemimpinan dan hubungan sosial serta pekerjaan itu sendiri.

Menurut Luthans (2011), ada beberapa faktor-faktor utama yang mempengaruhi kepuasan kerja, yaitu:

a. Pekerjaan itu sendiri. Yang termasuk pekerjaan yang memberikan kepuasan adalah pekerjaan yang menarik dan menantang, pekerjaan yang tidak membosankan, serta pekerjaan yang dapat memberikan status.

b. Upah/gaji. Upah dan gaji merupakan hal yang signifikan, tetapi merupakan faktor yang kompleks dan multidimensi dalam kepuasan kerja.

c. Promosi. Kesempatan dipromosikan nampaknya memiliki pengaruh yang beragam terhadap kepuasan kerja karena promosi bisa dalam bentuk yang berbedabeda dan bervariasi pula imbalannya.

d. Supervisi. Supervisi merupakan sumber kepuasan kerja lainnya yang cukup penting pula.

e. Kelompok kerja. Pada dasarnya, kelompok kerja akan berpengaruh pada kepuasan kerja. Rekan kerja yang ramah dan kooperatif merupakan sumber kepuasan kerja bagi pegawai individu.

f. Kondisi kerja/lingkungan kerja. Jika kondisi kerja bagus (misal lingkungan sekitar bersih dan menarik), maka pegawai akan lebih bersemangat mengerjakan pekerjaan mereka, namun bila kondisi kerja rapuh (misal lingkungan sekitar panas dan berisik), pegawai akan lebih sulit menyelesaikan pekerjaan mereka.

\section{Kinerja}

Satuan kinerja yang sudah ditetapkan terlebih dulu merupakan prestasi atau capaian prestasi sebagai sarana untuk mengukur kemampuan perusahaan dalam melakukan suatu pekerjaan (Kirom, 2015). Kinerja juga diartikan sebagai performance (Hassan \& Echols, 2003).

Kinerja individu dengan kinerja organisasi atau perusahaan sebagai hal saling terkait satu sama lain. Pencapaian hasil kerja secara perorangan atau sekelompok orang dalam organisasi dalam periode waktu tertentu yang dilakukan sesuai dengan tanggung jawab dan wewenangnya serta searah tujuan organisasi disebut sebagai kinerja (Soemohadiwidjoyo, 2015). Menurut Torang (2013) menggambarkan bahwa kinerja karyawan ditunjukkan dalam bentuk kuantitas dan atau kualitas hasil kerja baik secara individu atau kelompok yang sesuai dengan standar atau kriteria yang ditetapkan dalam organisasi.

Menurut Robin \& Judge (2013), kinerja berkaitan dengan umur, jenis kelamin, dan masa kerja. Bangun (2012) menyampaikaan pendapat bahwa pengukuran kinerja dapat dilakukan dengan metode tertentu yang meliputi kuantitas, kualitas, ketepatan waktu mengerjakannya, kehadiran, kemampuan bekerja sama yang dituntut suatu pekerjaan tertentu.

\section{METODE PENELITIAN}

Penelitian ini dilakukan dengan metode kuantitatif, menggunakan cara survei pada 
karyawan yang berada di Rumah Sakit Ortopedi Prof. Dr. R. Soeharso Surakarta. Rumah Sakit ini mempunyai karyawan berjumlah 628 orang, yang bekerja sebagai pejabat struktural, dokter, perawat, penunjang medis, dan administrasi tersebar pada berbagai unit kerja. Jumlah karyawan berdasarkan kategori masing-masing sebagai berikut: dokter berjumlah 30 orang, perawat 190 orang, penunjang medis 142 orang, dan administrasi 266 orang. Jumlah sampel ditentukan secara proporsional, teknik yang dilakukan adalah proportinate stratified random sampling. Penentuan jumlah sampel penelitian menggunakan rumus Slovin dan diperoleh jumlah 244 orang sampel. Berdasarkan perhitungan tersebut dapat ditentukan jumlah masing-masing kelompok, yaitu jumlah sampel minimal pada dokter sebanyak 12 orang, jumlah sampel minimal pada perawat sebanyak 74 orang, jumlah sampel minimal pada tenaga penunjang medis sebanyak 55 orang, dan sampel minimal pada tenaga administrasi minimal sebanyak 103 orang.

Data pada penelitian ini dengan menggunakan sumber primer dan sekunder. Perolehan data primer dilakukan dengan meminta dari subjek penelitian untuk mengisi kuesioner. Proses pengisian kuesioner dilakukan pada subjek di tempat kerja pada unit kerja masing-masing. Data sekunder diperoleh dari bagian SDM Rumah Sakit Ortopedi Prof. Dr. R. Soeharso Surakarta. Data sekunder meliputi jumlah karyawan, pendidikan, profesi karyawan, serta tempat unit kerja.

Penelitian ini dilakukan untuk mengetahui keterkaitan antara persepsi pentingnya akreditasi rumah sakit dengan partisipasi, komitmen, kepuasan kerja, dan kinerja karyawan. Teknik analilis data yang digunakan pada penelitian ini dengan menggunakan analisis jalur (path analysis). Seperti yang disampaikan oleh Haryono S. \& Wardoyo P. (2013) bahwa dalam analisis jalur merupakan perluasan dari analisis regresi berganda. Model jalur disusun untuk menghubungkan antara variabel exogen, perantara dan endogenous.

\section{Analisis Data Dan Pembahasan \\ 1. Analisis Deskripif}

Analisis deskriptif dimaksudkan untuk mengetahui karakteristik dan tanggapan responden. Responden dalam penelitian ini berjumlah 259 responden, yang terdiri dari administrasi sebanyak 112 responden; penunjang medis sebanyak 57 responden; perawat sebanyak 76 responden, serta dokter sebanyak 14 responden.

Gambaran umum 259 responden meliputi usia, jenis kelamin, status perkawinan, pendidikan terakhir, masa kerja, dan status kepegawaian. Tabel 1 menunjukkan bahwa sebagian besar responden berusia antara 36 sampai 48 tahun, berjenis kelamin pria sebanyak 141 responden dan wanita sebanyak 118 responden. Sebagian besar responden sudah menikah, dengan tingkat pendidikan terakhir responden sebagian besar SLTA sebanyak 88 orang, D3 sebanyak 85 orang, serta S1 sebanyak 62 orang. Berdasarkan masa kerja, sebagian besar memiliki masa kerja antara 13 tahun sampai 24 tahun. Dilihat dari status kepegawaian sebagian besar responden adalah PNS.

Tabel 1. Deskripsi Karakteristik Responden

\begin{tabular}{|c|c|c|}
\hline Karakteristik & Frekuensi & Persentase (\%) \\
\hline \multicolumn{3}{|c|}{ Usia } \\
\hline $23 \mathrm{~s} / \mathrm{d} 35$ tahun & 62 & 23,9 \\
\hline $36 \mathrm{~s} / \mathrm{d} 48$ tahun & 135 & 52,1 \\
\hline $49 \mathrm{~s} / \mathrm{d} 62$ tahun & 61 & 23,6 \\
\hline Tidak menjawab & 1 & 0,4 \\
\hline \multicolumn{3}{|c|}{ Jenis Kelamin } \\
\hline Pria & 141 & 54,4 \\
\hline Wanita & 118 & 45,6 \\
\hline \multicolumn{3}{|c|}{ Status Perkawinan } \\
\hline Kawin & 246 & 95 \\
\hline Tidak kawin & 12 & 4,6 \\
\hline Tidak menjawab & 1 & 0,4 \\
\hline \multicolumn{3}{|c|}{$\begin{array}{r}\text { Pendidikan Terakhir } \\
\end{array}$} \\
\hline SD & 3 & 1,2 \\
\hline SLTP & 3 & 1,2 \\
\hline SLTA & 88 & 34 \\
\hline
\end{tabular}




\begin{tabular}{ccc} 
D3 & 85 & 32,8 \\
S1 & 62 & 23,9 \\
S2 & 18 & 6,9 \\
\hline \multicolumn{3}{c}{ Masa Kerja } \\
\hline 1 s/d 12 tahun & 95 & 36,7 \\
13 s/d 24 tahun & 108 & 41,7 \\
25 s/d 38 tahun & 54 & 20,8 \\
Tidak menjawab & 2 & 0,8 \\
\hline \multicolumn{4}{c}{ Status Kepegawaian } \\
\hline \multicolumn{4}{c}{ PNS } & 210 & 81,1 \\
Non PNS & 49 & 18,9
\end{tabular}

Sumber: Hasil olahan data, 2016.

\section{Normalitas Data}

Normalitas univariate dan multivariate terhadap data yang digunakan dalam analisis ini. Tabel 2 terlihat hasil pengujian normalitas data dalam penelitian ini. Evaluasi normalitas diidentifikasi baik secara univariate maupun multivariate. Secara univariate untuk nilainilai dalam C.r skewness, semua item pernyataan menunjukkan nilai $<2$. Sedangkan untuk nilai-nilai dalam C.r kurtosis, semua item pernyataan menunjukkan nilai $<7$. Dengan demikian secara univariate terdistribusi normal.

Tabel 2. Hasil Uji Normalitas

\begin{tabular}{ccccccc}
\hline Variable & min & max & skew & c.r. & kurtosis & c.r. \\
\hline $\mathrm{ma}$ & 2.920 & 5.000 & -.273 & -1.795 & -.005 & -.017 \\
$\mathrm{pk}$ & 2.400 & 5.000 & -.289 & -1.899 & .071 & .232 \\
$\mathrm{kk}$ & 2.200 & 5.000 & -.266 & -1.746 & .513 & 1.685 \\
$\mathrm{ko}$ & 2.000 & 5.000 & -.230 & -1.509 & .222 & .731 \\
$\mathrm{kj}$ & 2.750 & 5.000 & .098 & .642 & .433 & 1.421 \\
Multivariate & & & & & 4.586 & 4.411 \\
\hline
\end{tabular}

Sumber: Hasil olahan data, 2016

Nilai yang tertera di pojok kanan bawah pada Tabel 2 menandakan bahwa data dalam penelitian ini juga terdistribusi normal secara multivariate dengan nilai C.r kurtosis 4,411; sehingga analisis selanjutnya masih dapat dilakukan.

Uji terhadap multivariate outliers dilakukan dengan menggunakan kriteria Jarak Mahalanobis pada tingkat $p<0,001$. Jarak Mahalanobis itu dievaluasi dengan menggunakan $\chi^{2}$ pada derajat bebas sebesar jumlah variabel indikator yang digunakan dalam penelitian (Ferdinand, 2005). Jika dalam penelitian ini digunakan 5 variabel indikator, semua kasus yang mempunyai Jarak Mahalanobis lebih besar dari $\chi^{2}$ $(5 ; 0,001)=20,515$ adalah multivariate outlier .

Tabel 3. Jarak Mahalanobis Data Penelitian

\begin{tabular}{cc}
\hline Observation number & Mahalanobis d-squared \\
\hline 245 & 19,427 \\
131 & 18,589 \\
130 & 18,084 \\
64 & 16,559
\end{tabular}

160 15,660

Sumber: Hasil olahan data, 2016

Tabel 3 menyajikan hasil evaluasi Jarak Mahalanobis. Dalam penelitian ini tidak ditemukan adanya kasus yang dapat dikategorikan sebagai outlier karena semua observasi memiliki jarak mahalanobis $<20,515$.

\section{Analisis Kesesuaian Model (Goodness- of-Fit)}

Tabel 4 menjelaskan hasil goodness of fit dari model penelitian yang dilakukan. Dalam pengujian ini nilai $\chi^{2}$ menghasilkan tingkat signifikansi lebih besar dari 0,05 dengan nilai $\chi^{2}$ sebesar 2,914 menunjukkan bahwa model penelitian yang diajukan sudah memenuhi. Nilai GFI, AGFI, TLI, dan CFI dalam model penelitian ini menunjukkan tingkat kesesuaian yang baik, sedangkan nilai CMIN/DF dan RMSEA menunjukkan tingkat kesesuaian yang kurang baik. Secara umum model yang diajukan menunjukkan tingkat kesesuaian yang baik. 
Tabel 4. Hasil Goodness-of-Fit Model

\begin{tabular}{cccc}
\hline Goodness-of-fit Indices & Cut-off Value & Hasil & Evaluasi Model \\
\hline Chi-Square $\left(\chi^{2}\right)$ & Diharapkan kecil & 2,914 & Fit \\
Degrees of freedom & Positif & 1 & Fit \\
Probability level $(p)$ & $\geq 0,05$ & 0,088 & Fit \\
CMIN/DF & $\leq 2,0$ & 2,914 & Tidak Fit \\
GFI & $\geq 0,90$ & 0,996 & Fit \\
AGFI & $\geq 0,90$ & 0,933 & Fit \\
TLI & $\geq 0,90$ & 0,957 & Fit \\
CFI & $\geq 0,90$ & 0,996 & Fit \\
RMSEA & $\leq 0,08$ & 0,086 & Tidak Fit \\
\hline
\end{tabular}

Sumber: Hasil olahan data, 2016

\section{Analisis Koefisien Jalur}

Tabel 5. Regression Weights

\begin{tabular}{ccccccc}
\hline & & & Estimate & S.E. & C.R. & P \\
\hline Partisipasi akreditasi & $<---$ & Persepsi manfaat akreditasi & .632 & .060 & 10.513 & .000 \\
Komitmen organisasional & $<---$ & Persepsi manfaat akreditasi & .178 & .074 & 2.414 & .016 \\
Kepuasan kerja & $<---$ & Persepsi manfaat akreditasi & .356 & .071 & 4.990 & .000 \\
Komitmen organisasional & $<---$ & Partisipasi akreditasi & .131 & .063 & 2.064 & .039 \\
Kepuasan kerja & $<---$ & Partisipasi akreditasi & .283 & .062 & 4.586 & .000 \\
Kinerja & $<---$ & Partisipasi akreditasi & .267 & .046 & 5.761 & .000 \\
Komitmen organisasional & $<---$ & Kepuasan kerja & .588 & .061 & 9.571 & .000 \\
Kinerja & $<---$ & Komitmen organisasional & .115 & .049 & 2.358 & .018 \\
Kinerja & $<---$ & Kepuasan kerja & .210 & .056 & 3.786 & .000 \\
\hline
\end{tabular}

Sumber: Hasil olahan data, 2016

Hasilpengujianpada Tabel5menunjukkan terlihat dari besarnya tingkat signifikansi (p) bahwa dari 9 jalur yang dianalisis, semua jalur uji hipotesis yang lebih kecil dari 5\%. yang memiliki hubungan yang signifikan,

Tabel 6. Pengaruh Langsung, Tidak Langsung dan Total

\begin{tabular}{llccc}
\hline \multicolumn{1}{c}{ Variabel } & \multicolumn{3}{c}{ Pengaruh $(\beta)$} \\
\hline \multicolumn{1}{c}{ Independen } & \multicolumn{1}{c}{ Dependen } & Langsung & Tidak langsung & Total \\
\hline Persepsi manfaat akreditasi & Partisipasi akreditasi & 0,548 & - & 0,548 \\
Persepsi manfaat akreditasi & Kepuasan kerja & 0,315 & 0,158 & 0,473 \\
Partisipasi akreditasi & & 0,289 & - & 0,289 \\
Persepsi manfaat akreditasi & \multirow{2}{*}{ Komitmen } & 0,140 & 0,312 & 0,452 \\
Partisipasi akreditasi & organisasional & 0,118 & 0,151 & 0,269 \\
Kepuasan kerja & & 0,522 & - & 0,522 \\
Persepsi manfaat akreditasi & & - & 0,370 & 0,370 \\
Partisipasi akreditasi & \multirow{2}{*}{ Kinerja } & 0,328 & 0,115 & 0,443 \\
Kepuasan kerja & & 0,253 & 0,081 & 0,334 \\
Komitmen organisasional & & 0,156 & - & 0,156 \\
\hline
\end{tabular}

Sumber: Hasil olahan data, 2016

Berdasarkan data pada Tabel 6 diketahui yaitu sebesar 0,548; sedangkan jalur yang bahwa jalur yang memiliki pengaruh langsung memiliki pengaruh tidak langsung paling yang paling besar adalah pengaruh persepsi besar adalah pengaruh persepsi manfaat manfaat akreditasi pada partisipasi akreditasi, akreditasi pada kinerja, yaitu sebesar 0,370. 
a. Pengaruh Persepsi Manfaat Akreditasi pada Partisipasi Akreditasi. Hasil analisis jalur menunjukkan nilai $\mathrm{CR}$ persepsi manfaat akreditasi pada partisipasi akreditasi sebesar 10,513 dengan tingkat signifikansi 0,000 , sehingga hipotesis 1 didukung dalam penelitian ini. Fenomena ini dapat terjadi karena seorang karyawan yang memiliki persepsi bahwa akreditasi akan membawa manfaat bagi perkembangan rumah sakit tempat dia bekerja, maka akan meningkatkan keinginan karyawan tersebut untuk berpartisipasi dalam proses persiapan akreditasi. Hasil penelitian ini konsisten dengan penelitian yang dilakukan oleh Wantouw et al., (2014) yang menunjukkan bahwa persepsi berpengaruh positif pada partisipasi.

b. Pengaruh Persepsi Manfaat Akreditasi pada Komitmen Organisasional. Hasil analisis jalur menunjukkan nilai CR persepsi manfaat akreditasi pada komitmen organisasional sebesar 2,414 dengan tingkat signifikansi 0,016 , sehingga hipotesis 2 didukung dalam penelitian ini. Fenomena ini dapat terjadi karena seorang karyawan yang memiliki persepsi bahwa akreditasi dapat membawa manfaat bagi perkembangan rumah sakit tempat dia bekerja akan meningkatkan keinginannya untuk tetap tinggal di tempat kerjanya. Hasil penelitian ini konsisten dengan penelitian yang dilakukan oleh Kalkavan \& Kaltrinli (2014) dan Madi et al., (2012) yang menunjukkan bahwa persepsi berpengaruh positif pada komitmen organisasional.

c. Pengaruh Persepsi Manfaat Akreditasi pada Kepuasan Kerja. Hasil analisis jalur menunjukkan nilai $\mathrm{CR}$ persepsi manfaat akreditasi pada kepuasan kerja sebesar 4,990 dengan tingkat signifikansi 0,000 , sehingga hipotesis 3 didukung dalam penelitian ini. Fenomena ini dapat terjadi karena seorang karyawan yang memiliki persepsi bahwa akreditasi dapat membawa manfaat bagi perkembangan rumah sakit tempat dia bekerja akan meningkatkan kepuasan kerja karyawan tersebut. Hasil penelitian ini konsisten dengan penelitian yang dilakukan oleh Shrivastava \& Purang (2009) dan Lambrou et al., (2014) yang menunjukkan bahwa persepsi berpengaruh positif pada kepuasan kerja.

d. Pengaruh Partisipasi Akreditasi pada Komitmen Organisasional. Hasil analisis jalur menunjukkan nilai $\mathrm{CR}$ partisipasi akreditasi pada komitmen organisasional sebesar 2,064 dengan tingkat signifikansi 0,039 , sehingga hipotesis 4 didukung dalam penelitian ini. Fenomena ini dapat terjadi karena seorang karyawan yang ikut berpartisipasi dalam proses persiapan akreditasi akan meningkatkan keinginannya untuk tetap tinggal di tempat kerjanya. Hasil penelitian ini konsisten dengan penelitian yang dilakukan oleh Bhatti \& Qureshi (2007) dan Bhatti et al., (2011) yang menunjukkan bahwa partisipasi berpengaruh positif pada komitmen organisasional.

e. Pengaruh Partisipasi Akreditasi pada Kepuasan Kerja. Hasil analisis jalur menunjukkan nilai $\mathrm{CR}$ partisipasi akreditasi pada kepuasan kerja sebesar 4,586 dengan tingkat signifikansi 0,000, sehingga hipotesis 5 didukung dalam penelitian ini. Fenomena ini dapat terjadi karena seorang karyawan yang ikut berpartisipasi dalam proses persiapan akreditasi akan meningkatkan kepuasan kerja yang dimilikinya. Hasil penelitian ini konsisten dengan penelitian yang dilakukan oleh Bhatti \& Qureshi (2007) dan Chapagai (2011) yang menunjukkan bahwa partisipasi berpengaruh positif pada kepuasan kerja.

f. Pengaruh Partisipasi Akreditasi pada Kinerja. Hasil analisis jalur pada menunjukkan nilai CR partisipasi akreditasi pada kinerja sebesar 5,761 dengan tingkat signifikansi 0,000 , 
sehingga hipotesis 6 didukung dalam penelitian ini. Fenomena ini dapat terjadi karena seorang karyawan yang ikut berpartisipasi dalam proses persiapan akreditasi akan meningkatkan kinerjanya. Hasil penelitian ini konsisten dengan penelitian yang dilakukan oleh Bhatti \& Qureshi (2007) dan Chughtai (2008) yang menunjukkan bahwa partisipasi berpengaruh positif pada kinerja.

g. Pengaruh Kepuasan Kerja pada Komitmen Organisasional. Hasil analisis jalur menunjukkan nilai CR kepuasan kerja pada komitmen organisasional sebesar 9,571 dengan tingkat signifikansi 0,039 , sehingga hipotesis 7 didukung dalam penelitian ini. Fenomena ini dapat terjadi karena seorang karyawan yang puas terhadap pekerjaannya akan meningkatkan keinginannya untuk tetap tinggal di tempat kerjanya. Hasil penelitian ini konsisten dengan penelitian yang dilakukan oleh Kim et al., (2005); Ho et al., (2009); Iqbal et al., (2014); dan Shah et al., (2014) yang menunjukkan bahwa kepuasan kerja berpengaruh positif pada komitmen organisasional.

h. Pengaruh Komitmen Organisasional pada Kinerja. Hasil analisis jalur menunjukkan nilai $\mathrm{CR}$ komitmen organisasional pada kinerja sebesar 2,358 dengan tingkat signifikansi 0,018, sehingga hipotesis 8 didukung dalam penelitian ini. Fenomena ini dapat terjadi karena seorang karyawan yang merasa menjadi bagian dari rumah sakit tempat dia bekerja akan meningkatkan kinerjanya. Hasil penelitian ini konsisten dengan penelitian yang dilakukan oleh Ahmad et al., (2010) dan Memari et al., (2013) yang menunjukkan bahwa komitmen organisasional berpengaruh positif pada kinerja. i. Pengaruh Kepuasan Kerja pada

Kinerja. Hasil analisis jalur menunjukkan nilai CR kepuasan kerja pada kinerja sebesar 3,786 dengan tingkat signifikansi 0,000, sehingga hipotesis 9 didukung dalam penelitian ini. Fenomena ini dapat terjadi karena seorang karyawan yang merasa puas dengan pekerjaannya akan meningkatkan kinerjanya. Hasil penelitian ini konsisten dengan penelitian yang dilakukan oleh Hira \& Waqas (2012) dan Javed et al., (2014) yang menunjukkan bahwa kepuasan kerja berpengaruh positif pada kinerja.

\section{Penutup}

Berdasarkan hasil penelitian dapat diambil beberapa kesimpulan, yaitu (1) persepsi manfaat akreditasi berpengaruh pada partisipasi akreditasi, (2) persepsi manfaat akreditasi berpengaruh pada komitmen organisasional, (3) persepsi manfaat akreditasi berpengaruh pada kepuasan kerja, (4) partisipasi akreditasi berpengaruh pada komitmen organisasional, (5) partisipasi akreditasi berpengaruh pada kepuasan kerja, (6) partisipasi akreditasi berpengaruh pada kinerja, (7) kepuasan kerja berpengaruh pada komitmen organisasional, (8) komitmen organisasional berpengaruh pada kinerja, dan (9) kepuasan kerja berpengaruh pada kinerja.

Berdasarkan hasil penelitian peneliti mengajukan beberapa saran, yaitu Peranan karyawan sangat dominan dalam dalam pelayanan pasien, sehingga upaya peningkatan mutu pelayanan perlu terus ditingkatkan. Upaya penyamaan persepsi terhadap pelayanan yang sesuai dengan standar akreditasi sangat penting, mengingat pelaksanaan akreditasi RS dapat menuntun para pelaksana pelayanan untuk bekerja sesuai standar yang ditetapkan. Penelitian lanjutan dapat dilakukan oleh peneliti berikutnya, dengan mengaitkan dengan perspektif mutu dari sisi pasien. 


\section{Daftar Pustaka}

Abolfotouh, M.A., AlKelya, M., AbuKhalid, N., Salam, M., Alamry, A.,. 2014. Nursing Perception Towards Impact of JCI Accreditation and Quality of Care in a Tertiary Care Hospital, Central Saudi Arabia. International Journal of Medicine and Medical Sciences. Vol. 47, No.1 hal. 1447-1460.

Ahmad, N., Iqbal, N., Javed, K., Hamad, N. 2014. Impact of Organizational Commitment and Employee Performance on the Employee Satisfaction. International Journal of Learning, Teaching and Educational Research. Vol. 1, No. 1, hal. 84-92.

Alas, R.,. 2007. The impact of employee participation on job satisfaction during change process. Problems and Perspectives in Management. Vol. 5, No. 4, hal. 28-33.

Allen, N.J., Meyer, J.P.,. 1990. The Measurement and antecedents of affective, continuance and normative commitment to the organization. Journal of Occupational Psychology. Vol. 63, hal. 1-18.

Badan Pengembangan dan Pembinaan Bahasa, Kemdikbud. 2016. Kamus Besar Bahasa Indonesia (KBBI). Jakarta.

Bahtti, K.K., Nawab, S., Akbar, A.,. 2011. Effect of Direct Participation on Organizational Commitment. International Journal of Business and Social Science Vol. 2 No. 9, hal. $15-23$.

Bangun, W. 2012. Manajemen Sumber Daya Manusia. Jakarta: Penerbit Erlangga.

Bhatti, K.K., Qureshi, T. M.,. 2007. Impact Of Employee Participation On Job Satisfaction, Employee Commitment And Employee Productivity. International Review of Business Research Papers Vol.3, No.2, hal.54 - 68.

Cahyono, S. B. 2008. Membangun Budaya Keselamatan Pasien dalam Praktik Kedokteran. Yogyakarta: Kanisius.

Caldwell, D. \& O'Reilly, C. 1982. Task Perceptions and Job Satisfaction : A Question of Causality. Journal of Applied Psychology Vol. 67, No. 3, hal. 361-369.

Casimir. G., Waldman.D.A., Bartram. T., Yang.S.,. 2006. Trust and the Relationship Between Leadership and Follower Performance: Opening the Black Box in Australia and China. Journal of Leadership \& Organizational Studies Vol.12, No.3, hal. 68-83.

Chapagai, R.R.,. 2011. Impact of Employee Participation on Job Satisfaction in Nepalese Commercial Banks. PYC Nepal Journal of Management Vol. 4, No. 1, hal. 39-41.

Chughtai,A.A. 2008. Impact of Job Involvement on In-Role Job Performance and Organizational Citizenship Behaviour. Institute of Behavioral and Applied Management. Dublin.

Dewi, A.A.S.K., 2006. Analisis Beberapa Faktor Yang Mempengaruhi Partisipasi Karyawan (Suatu Kajian Teori). Buletin Studi Ekonomi. Vol. 11 No. 1, hal. 10-18.

Diab, S.M., 2011. The Extent to Which Jordanian Doctors and Nurses Perceive the Accreditation. International Journal of Marketing Studies. Vol. 3, No. 1, hal. 78-94.

Ferwerda, J., Freese, C., 2011. Perceptions of organizational change and the psychological contract: A study on the influence of educational level.

Gibson, J.L., Ivancevich, J.M., Donnelly, J.H., Konopaske, R., 2012. Organizations: Behavior, Structure, Processes. Fourteenth Edition. New York: McGraw-Hill. 
Griffin, R.W., Ebert, R.J., 2007. Bisnis. Penerbit Erlangga. Vol. 2. Edited by W., Barnadi, D., Maulana, A., Hardani. Translated by S., Wardani. Jakarta: Penerbit Erlangga, Desember 24. hal. 55.

H, Echols J.M \& Shadily., 2003. Buku Kamus bahasa Inggris-Indonesia. Jakarta: PT Gramedia.

Haryono, S., Wardoyo P., 2013. Structural Equation Modelling untuk Penelitian Manajemen Menggunakan AMOS 18.00. Bekasi: Penerbit PT. Intermedia Personalia Utama.

Hira, A., Waqas, I., 2012. A Study of Job Satisfaction and IT's Impact on the Performance in the Banking Industry of Pakistan. International Journal of Business and Social Science Vol. 3, No. 19, hal. 174-180.

Ho, W. H., Chang, C. S., Shih, Y. L., \& Liang, R. D., 2009. Effects of Job Rotation and Role Stress Among Nurses on Job Satisfaction and Organizational Commitment. BMC Health Services Research 1-10.

Iqbal S., Ehsan S., Rizwan M., Noreen M., 2014. The Impact of Organizational Commitment, Job Satisfaction, Job Stress and Leadership Support on Turnover Intention in Educational Institutes. International Journal of Human Resource Studies Vol 4 , No. 2, hal.181-195.

James L. Gibson, John M. Ivancevich, James H. Donnelly, Jr., Konopaske R., 2012. Organizations: Behavior, Structure, Processes. New York: McGraw-Hill.

James, M., 2013. The Relationship between Organisational Commitment, Job Perfomance and Job Satisfaction Among Employees of Concern for the Girl Child Kampala Distict. Oktober. Accessed April 21, 2016. https://www.academia.edu/7815088/.

Javed, M., Balouch, R., Hassan, F., 2014. Determinants of Job Satisfaction and its Impact on Employee Performance and Turnover Intentions. International Journal of Learning \& Development Vol. 4, No. 2, hal. 120-140.

Javed, M., Balouch, R., Hassan, F., 2014. Determinants of Job Satisfaction and its Impact on Employee Performance and Turnover Intentions. International Journal of Learning \& Development Vol. 4, No. 2, hal. 120-140.

Kalkavan, S. \& Kaltrinli, A., 2014. The Effects Of Managerial Coaching Behaviors On The Employees' Perception Of Job Satisfaction, Organisational Commitment, And Job Performance: Case Study On Insurance Industry In Turkey. Procedia - Social and Behavioral Sciences hal. 1137 - 1147.

Kaswan, 2015. Sikap Kerja: Dari Teori dan Implementasi Sampai Bukti. Bandung: Alfabeta.

Khan, K., Nemati, A. R., 2011. Impact of job involvement on employee satisfaction: A study based on medical doctors working at Riphah. African Journal of Business Management Vol. 5, hal.2241-2246.

Khan, T.I., Jam, F.A., Akbar, A.,Khan, B.M., Hijazi, S.T., 2011. Job Involvement as Predictor of Employee Commitment: Evidence from Pakistan. International Journal of Business and Management. Vol. 6, No. 4, hal. 252-262.

Kim W.G., Leonga J.K., Leeb Y., 2005. Effect of Service Orientation on Jobsatisfaction, Organizational Commitment, and Intention of Leaving in a Casual Dining Chain Restaurant. International Journal of Hospitality Management. hal. 171-193.

Kirom, B., 2015. Mengukur Kinerja Pelayanan dan Kepuasan Konsumen. Bandung: Pustaka Reka Cipta. 
Kotler, P., Keller, K.L., 2012. Marketing Management. New Jersey: Prentice Hall.

Kuncoro, M., 2013. Metode Riset untuk Bisnis \& Ekonomi. Jakarta: Penerbit Erlangga.

Lambrou, P., Merkouris, A., Middleton, N., Papastavrou, E. 2014. Nurses' Perceptions of Their Professional Practice Environment in Relation to Job Satisfaction: a Review of Quantitative Studies. Health Science Journal. Vol. 8, No.3, hal 298-317.

Lee, M., 2010. The Pursuit of Accreditation in Children's Mental Health Care: Motivations, Experiences, and Perceptions. Washington University in St. Louis, Open Scholarship.

Luarn, P., Huang, K.,. 2009. Factors Influencing Government Employee Performance via Information Systems Use: an Empirical Study. Electronic Journal of e-Government. Vol. 7, No. 3, hal. 227-240.

Luthans, F., 2011. Organizational Behavior, An Evidence-Based Approach. Twelfth Edition. New York: McGraw-Hill.

Madi, M., Abu-Jarad, I., Alqahtani, A., 2012. Employees' Perception and Organizational Commitment: A Study on the Banking Sector in Gaza, Palestine. International Journal of Business and Social Science. Vol. 3, No. 16, hal. 299-312.

Manzo, B.F., Ribeiro, H.C.T.C., Brito, M.J.M., Alves, M.,. 2012. Nursing in the Hospital Accreditation Process: Practice and Implications in the Work Quotidian. Rev. Latino-Am. Enfermagem. Vol. 20, No.1, hal. 151-158.

Memari, N., Mahdieh, O., \& Marnani, A. B. 2013., The impact of Organizational Commitment on Employees Job Performance: a study of Meli bank. Interdisciplinary Journal of Contemporary Research In Business. Vol. 5, No. 5, hal. 164-171.

Morrison, L., Steinfeldt, C., Lincoln, S., Schmidt S., Gage, M., Pfaff N., 2008. Job Performance Standards. Enterprise Management Development Academy.

Mowday, R.T., Porter, L.W., and Steers, R. M.,. 1979. The Measurement of Organizational Commitment. Journal of Vocational Behavior. hal. 224-227.

Nasution, S., 2014. Metode Research (Penelitian Ilmiah). Jakarta: PT Bumi Aksara.

Obicci, P.A., 2014. Determinants of Employee Commitment for Organizational Performance. International Journal of Management Academy. Vol. 2, No. 4, hal. 37-44.

Permenkes. Tahun 2012. Peraturan Menteri Kesehatan RI nomor 12 tahun 2012 tentang Akreditasi Rumah Sakit.

Price, J. L., \& Mueller, C. W. 1986. Handbook of Organizational Measurement. Marshfield: Pitman.

R.I, Departemen Kesehatan. 2006. Buku Panduan Nasional Keselamatan Pasien di Rumah Sakit. Jakarta.

Rahma, P.A. 2012. Akreditasi Rumah Sakit, Pengakuan Atas Kualitas Layanan. Mutu Pelayanan Kesehatan. Oktober. Accessed Maret 26, 2016. http://mutupelayanankesehatan.net/ index.php/component/content/article/19-headline/151.

RI, Direktorat Jendral Bina Upaya Kesehatan Kementerian Kesehatan. 2016. Rumah Sakit Online. Accessed April 9, 2016. http://sirs.buk.depkes.go.id/ rsonline/report.

Riduwan. 2014. Dasar-dasar Statistika. Bandung: Penerbit Alfabeta.

Robbin, S.P., Coulter, M.,. 2012. Management, 11 th. New Jersey: Prentice Hall. 
Robbins, P.S., Judge, T.A.,. 2013. Organizational Behavior. New York: Prentice Hall.

Saeed, R., Mussawar S., Lodhi, R.N., Iqbal, A., Hafiza Hafsa Nayab, H.H., Yaseen, S.,. 2013. Factors Affecting the Performance of Employees at Work Place in the Banking Sector of Pakistan. Middle-East Journal of Scientific Research. Vol. 17, No. 9, hal. 1200-1208.

Selanno, H.,. 2014. Faktor Internal yang Mempengaruhi Perilaku Organisasi. Populis, Vol. 8, No. 2, hal. 44-56.

Shah F.T., Idrees F., Imam A., Khan T.A.,. 2014. Impact of Job Satisfaction on Organizational Commitment in IT Sector Employees of Pakistan. Journal of Applied Environmental and Biological Sciences Vol. 4, No. 8, hal. 190-197.

Shrivastava, A. \& Purang, P.,. 2009. Employee Perceptions Of Job Satisfaction: Comparative Study On Indian Banks. Asian Academy of Management Journal Vol. 14, No. 2, hal. 6578 .

Sjobergi A., Sverke M.,. 2000. The interactive effect of job involvement and organizational commitment on job turnover revisited: A note on the mediating role of turnover intention. Scandinavian Journal of Psychology Vol. 41, hal. 247-252.

Soemohadiwidjoyo, A.T.,. 2015. Panduan Praktis Menyusun KPI (Key Performance Indicator). Jakarta: Penerbit Raih Asa Sukses.

Sugiyono. 2013. Metode Penelitian Manajemen. Bandung: Penerbit Alfabeta.

Sutoto. 2013. Perubahan Paradigma Akreditasi Versi 2012 untuk Asesor Internal. Workshop Para Pimpinan Rumah Sakit. Jakarta, Juni 28-29.

Sutoto, Atmodjo, D., Luwiharsih, Lumenta N.A., Reksoprojo, M., Martoatmodjo, K., Atmatyah, M., Saleh J.T. 2013. Pedoman Tata Laksana Survei Akreditasi Rumah Sakit. Jakarta.

Sutradhar, T.,. 2014. Influence of perception on organizational behaviour. Slideshare. September 28. Accessed April 3, 2016. http://www.slideshare.net/tirthnkr/influence-of-perceptionon-organizational-behaviour?from_action=save.

Theo, D.,. 2009. Pengaruh Persepsi Pimpinan tentang Mutu Instalasi Gawat Darurat terhadap Pelaksanaan Akreditasi Rumah Sakit di Kota Medan. USU Institutional Repository (USU-IR).

Tolentino, R. 2013. Organizational Commitment and Job Performance of the Academic and Administrative Personnel. International Journal of Information Technology and Business Management. Vol.15, No.1 hal. 51-59.

Torang, S.,. 2013. Organisasi dan Manjemen: Perilaku, Struktur, Budaya dan Perubahan Oganisasi. Bandung: Penerbit Alfabeta.

Wantouw, S., Antariksa, Bagyo Yanuwiadi, B., Tamod, Z., 2014. Perception and Participation on Co-Management of Green Open Space in Coastal Reclamation Area Manado. International Journal of Applied Sociology. hal. 108 - 113.

Wright. T.A., Cropanzano. R.,. 2000. Psychological Well-Being and Job Satisfaction as Predictors of Job Performance. Journal of Occupational Health Psychology. Vol.5, Hal.1, hal. 84-94.

Yan, Y. \& Kung, C. 2015. The Impact of Hospital Accreditation System : Perspective of Organizational Learning. Scientific Research an Academic Publisher. hal. 1081-1089. 
Yildiz, A., Kaya, S.,. 2014. Perceptions of nurses on the impact of accreditation on quality of care : A survey in a hospital in Turkey. Clinical Governance: An International Journal. Vol. 19, No. 2, hal. 69-82. 